\title{
PENGARUH LINGKUNGAN KERJA DAN STRES KERJA TERHADAP KINERJA KARYAWAN (STUDI KASUS PT. MODERNLAND REALTY, TBK)
}

\author{
Aidil Amin Effendy ${ }^{1)}$ \& Juwita Ramadani Fitria ${ }^{2)}$ \\ 1) dosen universitas pamulang, email : aidilamineffendy@gmail.com \\ 2) dosen universitas pamulang, email : juwita liem999@yahoo.com
}

\section{ARTICLES INFORMATION}

\section{ABSTRACT}

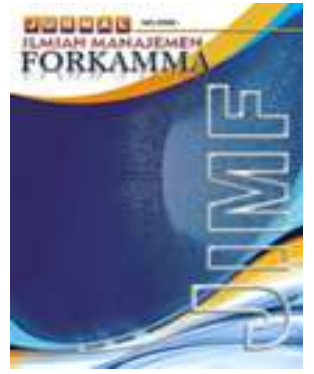

\section{JURNAL ILMIAH MANAJEMEN FORKAMMA}

\author{
Vol.2, No.2, Maret 2019 \\ Halaman :49-61 \\ (c) LPPM \& FORKAMMA
}

Prodi Magister Manajemen UNVERSITAS PAMULANG

$$
\begin{array}{cc}
\text { ISSN (online) } & : 2599-171 X \\
\text { ISSN (print) } & : 2598-9545
\end{array}
$$

\section{Keyword:}

Work environment, work stress, employee performance

JEL. classification :

O15,

\section{Contact Author :}

$$
\begin{gathered}
\text { PRODI } \\
\text { MAGISTER MANAJEMEN \& } \\
\text { FORKAMMA UNPAM } \\
\text { JL.Surya Kencana No.1 Pamulang } \\
\text { Tangerang Selatan - Banten } \\
\text { Telp. (021) 7412566, Fax (021) } 7412491 \\
\text { Email: } \\
\text { jurnalforkamma.unpam@gmail.com }
\end{gathered}
$$

Tujuan penelitian ini untuk mengetahui "Seberapa besar pengaruh Lingkungan Kerja dan Stres Kerja terhadap Kinerja Karyawan pada PT. Modernland Realty, Tbk, Jakarta Selatan." Pada penelitian ini, variabel independen yaitu Lingkungan Kerja (X1) dan Stres Kerja (X2), sedangkan variabel dependen adalah Kinerja Karyawan ( $Y$ ). Jenis penelitian merupakan penelitian kuantitatif dianalisis menggunakan statistik. Adapun jumlah sampel diperoleh dengan menggunakan sampel jenuh yaitu menjadikan seluruh populasi karyawan PT. Modernland Realty, Tbk menjadi sampel yang berjumlah 70 responden. Analisis data menggunakan SPSS Versi 21. Teknik uji sampling menggunakan metode sensus dan teknik pengambilan data diantaranya "Uji validitas, uji reliabilitas, uji asumsi klasik meliputi uji normalitas, multikolinieritas, heterokedastisitas, serta Uji Regresi Linier Berganda, Uji Koefisien Korelasi, Uji Koefisien Determinasi, dan Uji Hipotesis." Hasil penelitian menunjukan bahwa "Lingkungan Kerja dan Stres Kerja secara simultan memiliki pengaruh sebesar $47,7 \%$ terhadap Kinerja Karyawan, sedangkan sisanya sebesar $52,3 \%$, dipengaruhi oleh faktor lain yang tidak diteliti pada penelitian ini."

The purpose of this study is "To find out how much influence the Work Environment and Job Stress have on Employee Performance at PT. Modernland Realty, Tbk, South Jakarta." In this study, the independent variables are Work Environment (X1) and Job Stress (X2), while the dependent variable is Employee Performance $(Y)$. This type of research is quantitative research analyzed using statistics. The number of samples obtained by using saturated samples is to make the entire population of employees of PT. Modernland Realty, Tbk is a sample of 70 respondents. Analysis of data using SPSS Version 21. The sampling test technique uses census methods and data collection techniques including "Validity test, reliability test, classic assumption test includes normality test, multicollinearity, heterocedasticity, and Multiple Linear Regression Test, Correlation Coefficient Test, Determination Coefficient Test, and Hypothesis testing." The results showed that "The Work Environment and Job Stress simultaneously had an influence of $47.7 \%$ on Employee Performance, while the remaining amounted to $52.3 \%$, influenced by other factors not examined in this study." 


\section{A. Pendahuluan}

Salah satu fungsi manajemen adalah pengorganisasian yaitu bagaimana perusahaan dapat mengatur sumber daya manusia agar efektif dan mengerahkan kemampuannya dalam mengembangkan kinerja terbaiknya. Namun disini juga diperlukan fungsi manajemen selanjutnya ialah pengawasan, dimana peran seorang manager dalam mengawasi bawahannya yaitu sumber daya manusia agar dapat bekerja secara profesional dan disiplin dalam bekerja.

Sumber daya manusia yang unggul dan kompetitif sangatlah dibutuhkan dalam perusahaan dalam menjalankan aktivitas kinerja perusahaan yang dapat bersaing dengan perusahaan sejenis lainnya, namun faktor-faktor yang menjadi kendala terhambatnya peluang perusahaan dalam bersaing haruslah diatasi oleh seorang manager, salah satu yang mungkin perlu diperhatikan adalah faktor lingkungan kerja yang kondusif antar karyawan dan antar pimpinan dengan bawahan, juga perlunya lingkungan yang aman dan nyaman bagi karyawan dalam bekerja, sehingga dapat menghasilkan kinerja yang efektif dan efisien.

Menurut Sadarmayanti (2001:31), "Lingkungan kerja adalah semua keadaan yang terjadi yang berkaitan dengan hubungan kerja, baik hubungan dengan atasan maupun hubungan sesama rekan kerja, ataupun hubungan dengan bawahan". Maka dapat disimpulkan lingkungan kerja perlu diperhatikan agar karyawan dapat semakin meningkatkan kemampuan dan semangat kerja sehingga dapat menghasilkan kinerja yang baik.

Stres juga merupakan hal yang perlu dihindari oleh para karyawan dalam bekerja yang mengakibatkan penurunan kinerja yang dapat mempengaruhi efektivitas produksi suatu perusahaan. Menurut Sondang P.siagian (2016: 300) "Stres merupakan kondisi ketegangan yang berpengaruh terhadap emosi, jalan pikiran dan kondisi fisik seseorang. stress yang tidak di atasi dengan baik biasanya berakibat pada ketidak mampuan sesorang berinteraksi secara positif, baik dalam arti lingkungan pekerjaan maupun luarnya."

Lingkungan kerja yang kondusif dan nyaman, juga diperhartikannya tingkat stress kerja karyawan oleh seorang manager dapat meningkatkan kinerja yang efektif dari seorang karyawan. Kinerja menurut Cormick dan Tiffin dalam Edy Sutrisno (2010:172) mengemukakan kinerja adalah "Kuantitas, kualitas, dan waktu yang digunakan dalam menjalankan tugas, kuantitas adalah hasil yang dapat dihitung sejauh mana seseorang dapat berhasil mencapai tujuan yang telah ditetapkan, adapun kualitas adalah bagaimana seseorang dalam menjalankan tugasnya, yaitu mengenai banyaknya kesalahan yang dibuat, kedisiplinan dan ketepatan, kemudian Waktu kerja adalah mengenai jumlah absen yang dilakukan, keterlambatan, dan lamanya masa kerja dalam tahun yang dijalani."

Maka dapat disimpulkan, perusahaan yang mampu bersaing adalah perusahaan yang dapat meningkatkan kinerja karyawannya. Dalam meningkatkan kinerja karyawan, faktor lingkungan kerja dan stres kerja karyawan sangatlah perlu diperhatikan dalam menciptakan efektivitas produksi, efisiensi biaya dan penjualan maksimal sehingga perusahaan dapat mampu bersaing dengan perusahaan sejenis lainnya.

Penelitian ini mengambil obyek penelitian pada PT. Modernland Realty yang merupakan perusahaan bergerak di bidang jasa property rumah. Kegiatan yang dilakukan PT. Modernland Realty adalah membangun rumah . Pada PT. Modernland Realty sangat membutuhkan kinerja karyawan yang tinggi untuk meningkatkan produktivitas perusahaan, oleh karena itu salah satunya adalah dengan meminimalisir stres kerja dan menciptakan lingkungan kerja yang baik serta kondusif. Untuk itulah, maka langkah-langkah yang dilakukan untuk mengurangi stres kerja sangat diperlukan. Berdasarkan uraian di atas, maka penulis tertarik untuk mengambil 
pembahasan mengenai Manajemen Sumber Daya Manusia yang berjudul : "Pengaruh Lingkungan Kerja Dan Stress Kerja Terhadap Kinerja Karyawan (Studi Kasus PT. Modernland Realty, Tbk)".

\section{B. Perumusan Masalah}

Berdasarkan latar belakang yang telah diungkapkan di atas, maka rumusan masalah dalam penelitian ini adalah :

1. Seberapa besar pengaruh Lingkungan Kerja terhadap Kinerja Karyawan?

2. Seberapa besar pengaruh Stres Kerja terhadap Kinerja Karyawan ?

3. Seberapa besar pengaruh Lingkungan Kerja dan Stres Kerja terhadap Kinerja Karyawan secara simultan?

C. Kerangka Berpikir

Kerangka berfikir penelitian ini dapat digambarkan sebagai berikut:

\section{PENGARUH LINGKUNGAN KERJA DAN STRES KERJA TERHADAP KINERJA KARYAWAN PADAPT. MODERNLAND REALTY, TBK - JAKARTA}

Lingkungan Kerja $\left(\mathrm{X}_{1}\right)$ Indikator :

1. Penerangan

2. Suhu udara

3. Suara bising

4. Penggunaan warna

5. Ruang gerak yang diperlukan

6. Keamanan kerja

7. Hubungan karyawan

Sedarmayanti (2001:46)

Stres Kerja $\left(\mathrm{X}_{2}\right)$

Indikator :

1. Beban Kerja

2. Waktu Kerja

3. Penilaian Kinerja

4. konflik

Sondang P. Siagian(2015: 301)

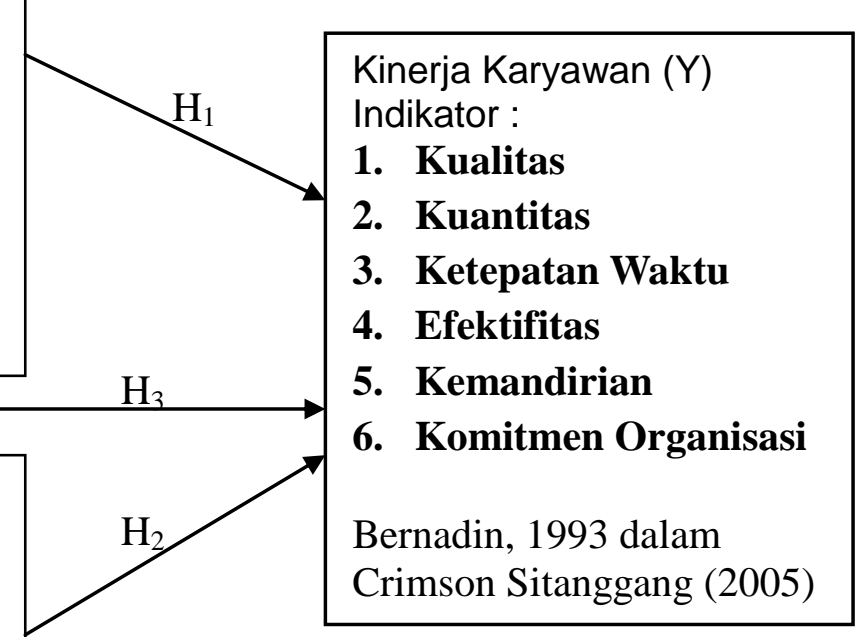

Gambar. 1.1

Kerangka Berpikir

\section{Landasan Teori}

\section{Lingkungan Kerja}

Menurut Sadarmayanti (2001:31), "Lingkungan kerja non fisik adalah semua keadaan yang terjadi yang berkaitan dengan hubungan kerja, baik hubungan dengan atasan maupun hubungan sesama rekan kerja, ataupun hubungan dengan bawahan".

"Lingkungan non fisik ini juga merupakan kelompok lingkungan kerja yang tidak bisa diabaikan." Menurut Alex Nitisemito (2000:171-173) "Perusahaan hendaknya dapat mencerminkan kondisi yang mendukung kerja sama antara tingkat atasan, bawahan 
maupun yang memiliki status jabatan yang sama di perusahaan. Kondisi yang hendaknya diciptakan adalah suasana kekeluargaan, komunikasi yang baik, dan pengendalian diri."

Suryadi Perwiro Sentoso (2001:19-21) yang mengutip pernyataan Prof. Myon Woo Lee sang pencetus teori W dalam IImu Manajemen Sumber Daya Manusia, "bahwa pihak manajemen perusahaan hendaknya membangun suatu iklim dan suasana kerja yang bisa membangkitkan rasa kekeluargaan untuk mencapai tujuan bersama. Pihak manajemen perusahaan juga hendaknya mampu mendorong inisiatif dan kreativitas. Kondisi seperti inilah yang selanjutnya menciptakan antusiasme untuk bersatu dalam organisasi perusahaan untuk mencapai tujuan."

\section{Stres Kerja}

Menurut Sondang P.siagian (2016: 300) "Stres merupakan kondisi ketegangan yang berpengaruh terhadap emosi, jalan pikiran dan kondisi fisik seseorang. stress yang tidak di atasi dengan baik biasanya berakibat pada ketidak mampuan sesorang berinteraksi secara positif, baik dalam arti lingkungan pekerjaan maupun luarnya."

Menurut Veithzal Rivai (2014: 724), "Stres kerja adalah suatu kondisi ketegangan yang menciptakan adanya ketidak seimbangan fisik dan psikis yang mempengaruhi emosi, proses berfikir, dan kondisi seorang karyawan, apabila stress yang terlalu besar dapat mengancam kemampuan seseorang untuk menghadapi lingkungan."

Apabila karyawan mengalami stres dalam suatu perusahaan, sangat besar kemungkinan hal tersebut akan menghambat jalannya interaksi antar sesama karyawan dan biasanya karyawan yang mengalami stress akan menjadi agresif dan mudah marah sehingga dapat memicu terjainya konflik antar sesama karyawan sehingga hal tersebut dapat berdampak pula pada kinerja yang di hasilkan.

\section{Kinerja Karyawan}

"Kinerja karyawan adalah perbandingan hasil kerja nyata karyawan dengan standar kerja yang telah ditetapkan oleh perusahaan." (Crimson Sitanggang, 2005). Menurut Crimson, "Setiap perusahaan didalam rekrutmen sumber daya manusia pastilah akan memilih orang- orang yang memenuhi kriteria yang sudah ditetapkan oleh perusahaan, hal ini bertujuan agar mendapatkan karyawan yang berkualitas yang dapat mengemban tugas organisasi sehingga tujuan perusahaan dapat terlaksana, untuk itu kinerja karyawan merupakan keharusan agar dapat terwujud kinerja organisasi."

Cormick dan Tiffin dalam Edy Sutrisno (2010:172) mengemukakan kinerja adalah "Kuantitas, kualitas, dan waktu yang digunakan dalam menjalankan tugas, kuantitas adalah hasil yang dapat dihitung sejauh mana seseorang dapat berhasil mencapai tujuan yang telah ditetapkan, adapun kualitas adalah bagaimana seseorang dalam menjalankan tugasnya, yaitu mengenai banyaknya kesalahan yang dibuat, kedisiplinan dan ketepatan, kemudian Waktu kerja adalah mengenai jumlah absen yang dilakukan, keterlambatan, dan lamanya masa kerja dalam tahun yang dijalani."

Menurut para ahli diatas, penulis menyimpulkan bahwa kinerja dapat didefinisikan sebagai "hasil kerja yang dapat dicapai oleh seseorang atau sekelompok orang dalam suatu organisasi, yang dimulai dari proses awal sampai akhir sebagai hasil yang didapat."

\section{E. Metodologi Penelitian}

Jenis penelitian merupakan penelitian kuantitatif, Metode kuantitatif menurut Sugiyono (2013:8) adalah "Metode penelitian yang berlandaskan pada filasafat positivism, digunakan utuk meneliti pada populasi atau sampel tertentu, pengumpula data mengga instrument penelitian, analisis data bersifat kuantitatif/ satatistik, dengan tujuan untuk menguji hipotesis yang telah ditetapkan." Penelitian ini bertujuan untuk mengetahui pengaruh Lingkungan Kerja, dan Stres Kerja Terhadap Kinerja Karyawan pada PT. Modernland Realty, Tbk 


\section{Populasi Dan Sampel}

1. Populasi

Populasi menurut Sugiyono (2006:90) adalah "Wilayah generalisasi yang terdiri dari obyek atau subyek yang menjadi kualitas dan karakteristik tertentu yang ditetapkan oleh peneliti untuk dipelajari dan kemudian ditarik kesimpulannya." Berdasarkan pada tempat penelitian yang telah ditetapkan, maka populasi yang dijadikan objek dalam penelitian ini adalah karyawan pada PT. Modernland Realty, Tbk yang berjumlah 70 responden.

\section{Sampel}

Sampel menurut Sugiyono (2006:96) adalah "Bagian dari populasi yang dipergunakan sebagai sumber data yang sebenarnya. Dengan kata lain, sampel merupakan bagian dari populasi." Pembagian jenis sampel yang diterapkan oleh Sugiyono (2006:96), "Ada berbagai macam. Diantaranya penulis menerapkan dalam penelitian dengan menggunakan sampel Jenuh atau sampling Jenuh, dimana teknik pengumpulan sampel bisa semua anggota populasi digunakan sebagai sampel. Hal ini sering dilakukan bila jumlah populasi dianggap kecil atau kurang dari 100 orang atau responden." Adapun sampel di penelitian ini yaitu 70 responden, sesuai jumlah populasi seluruh jumlah karyawan di perusahaan.

\section{Analisis Data}

Analisis data Analisis data yang digunakan dalam penelitian ini adalah uji validitas dan uji reliabilitas. Menurut Mas'ud (2004:29), "Agar dapat memperoleh data dari responden dengan baik, kuesioner sebagai instrumen pengumpulan data penelitian harus memenuhi persyaratan validitas dan reabilitas. Untuk itu kuesioner tersebut harus diuji terlebih dahulu tingkat validitas dan reliabilitas. Pengujian validitas menggunakan rumus korelasi pearson product moment, dengan ketentuan jika $r$ hitung $>r$ tabel, berarti instrumen valid." Adapun pengujian realibilitas menurut Ghozali (2005: 46), "Suatu variabel penelitian dikatakan reliabel apabila memenuhi kriteria sebagai berikut: jika Cronbach Alpha $>$ 0,6 dinyatakan reliable dan Jika Cronbach Alpha $<0,6$ dinyatkan tidak reliabel." Teknik analsis data antara lain uji asumsi klasik dan analisis regresi ganda. Uji asumsi klasik terdiri dari uji normalitas, uji multikolinearitas dan uji heteroskedastisitas

\section{Uji Normalitas}

Menurut Ghozali (2005: 73), "Uji normalitas digunakan untuk melihat apakah nilai residual terdistribusi normal atau tidak. Model regresi yang baik adalah memiliki nilai residual yang terdistribusi normal. Jadi uji normalitas bukan dilakukan pada masingmasing variabel tetapi pada nilai residualnya." Ghozali juga menjelaskan, "Untuk mendeteksi apakah residual berdistribusi normal atau tidak yaitu dengan melihat normal probability plot dan one sampel kolmogrof smirnov test yang membandingkan distribusi kumulatif dari distribusi normal. Normalitas pada probability plot dapat dideteksi dengan melihat penyebaran dan (titik) pada sumbu diagonal dari grafik. Jika ada (titik) menyebar disekitar garis diagonal maka menunjukkan pola distribusi normal pada one sampel kolmogrof smirnov testAsymp. Sig 2 (vailed) nilai keakuratan 95\% berarti nilai signifikan/Sig 0,05 nilai pada uji ini harus diatas 0,05 yang mengindikasikan bahwa model regresi memenuhi asumsi normal."

\section{Uji Multikolinearitas}

Menurut Ghozali (2005:91), “Uji multikolineritas bertujuan untuk menguji apakah model regresi menemukan adanya korelasi antar variable bebas (independen), model regresi yang baik seharusnya tidak terjadi korelasi diantara variable independen." Ghozali juga menjelaskan, "Dalam penelitian ini uji multikolinieritas digunakan untuk menguji apakah ada korelasi diantara Variable Lingkungan Kerja, dan Stres Kerja. Model regresi 
yang tidak ada multikolinieritas adalah yang mempunyai nilai besaran korelasi antar variable bebas kurang dari 95\% VIF (Variance Inflation Factor) kurang dari 10 dan mempunyai nilai tolerance lebih dari 0.1 atau $10 \%$."

\section{Uji Heterokedastisitas}

Menurut Ghozali (2005:93), "Bertujuan menguji apakah dalam model regresi terdapat ketidaksamaan variance dan residual satu pengamatan ke pengamatan yang lain. Jika variance dari residual satu pengamatan ke pengamatan lain tetap, maka disebut homoskedastisitas, karena data ini menghimpun data yang mewakili berbagai ukuran (kecil, sedang dan besar)."

\section{Analisis Regresi Ganda}

Menurut Sugiyono (2009:277) yaitu: "Analisis yang digunakan peneliti, bila bermaksud bagaimana keadaan (naik turunnya) variable dependen (kriterium), bila dua atau lebih variable independen sebagai faktor prediktor dimanipulasi (dinaik turunkan nilainya)". Sugiyono juga menjelaskan, "Pengujian yang digunakan dalam penelitian ini menggunakan analisis metode regresi linier berganda dengan tingkat tarif signifikansi $\mathrm{I}=$ 0,05 artinya derajat kesalahan sebesar $5 \%$, tujuannya untuk mengetahui pengaruh insentif dan motivasi terhadap kinerja."

Teknik analisis regresi ganda dipergunakan untuk "Mengetahui pengaruh Lingkungan Kerja dan Stres Kerja terhadap Kinerja Karyawan PT. Modernland Realty, Tbk. Dengan persamaan regresi $Y=a+b_{1} X_{1}+X_{2} b_{2}+X_{3} b_{3}$."

\section{Koefisien Korelasi}

Pengujian koefisien korelasi ini digunakan untuk "Mengetahui kekuatan hubungan antara korelasi kedua variabel dimana variabel lainnya yang dianggap berpengaruh dikendalikan atau dibuat tetap (sebagai variabel kontrol), karena variabel yang diteliti adalah interval maka teknik statistik yang diguanakan adalah Pearson Correlation Product Moment." (Sugiyono, 2013:216).

\section{Koefisien Determinasi}

Menurut Umi Narimawati (2010:50), Pengujian koefisien determinasi bertujuan "Untuk mengetahui besarnya pengaruh antar variabel, nilai koefisien determinasi menunjukkan presentase variasi nilai variabel dependen yang dapat dijelaskan oleh persamaan regresi yang dihasilkan." Adapun perhitungan uji ini dilakukan dalam menghitung "Besarnya pengaruh Lingkungan kerja (X1) dan Stres Kerja (X2) terhadap Kinerja Karyawan ( $\mathrm{Y}$ ) dapat diketahui dengan menggunakan analisis koefisien determinasi atau disingkat $\mathrm{Kd}$ yang diperoleh dengan mengkuadratkan koefisien korelasinya."

\section{Uji Hipotesis}

1. Uji T

Menurut Priyatno (2012:58-59), "Uji $t$ ini bertujuan untuk mengetahui besarnya pengaruh masing-masing variabel independent secara individual (parsial) terhadap variabel dependen, pengujian dengan berdasarkan probabilitas: Tingkat signifikansi yang digunakan sebesar 5\%, hal ini berarti tingkat kepercayaan adalah 95\% (100\% - 5\%)."

\section{Uji F}

Menurut Priyatno (2012:55-56), "Uji F digunakan untuk menguji pengaruh variabel independen secara bersama-sama terhadap variabel dependen." Priyatno juga menjelaskan "Uji statistik F pada dasarnya menunjukkan apakah semua variabel bebas yang dimasukkan dalam model mempunyai pengaruh secara bersama- sama terhadap 
variabel dependen untuk mengambil keputusan hipotesis diterima atau ditolak dengan membandingkan tingkat signifikasi sebesar 0,05."

Menurut Ghozali (2005:84), "Jika nilai probability F lebih besar dari 0,05 maka model regresi tidak dapat digunakan untuk memprediksi variabel dependen atau dengan kata lain variabel independen secara bersama-sama tidak berpengaruh terhadap variabel dependen."

\section{F. Hasil Analisis Data dan Hasil Penelitian \\ 1. Uji Validitas dan Uji Reliablitas}

Hasil uji validitas dengan menggunakn rumus korelasi product moment dan membandingkan dengan $r$ tabel dengan taraf siginfikansi sebsar $5 \%$ maka diperoleh $r$ tabel yaitu 0,235 sehingga berikut ini hasil intrumen kusiner no 1 untuk setiap variabel diperoleh nilai:

a. Lingkungan Kerja, instrument kuisioner no 1 diperoleh nilai $r$ hitung $(0,946)>r$ tabel $(0,235)$ sehingga instrument no 1 dikatakan valid.

b. Stres Kerja instrument kuisioner no 1 diperoleh nilai $r$ hitung $(0,816)>r_{\text {tabel }}(0,235)$ sehingga instrument no 1 dikatakan valid.

c. Kinerja Karyawan instrument kuisioner no 1 diperoleh nilai $r$ hitung $(0,915)>r_{\text {tabel }}$ $(0,235)$ sehingga instrument no 1 dikatakan valid.

Setelah dilaukan uji validitas dan seluruh intrumen di nyatakan valid, maka tahap selanjut nya adlaah uji reliabilitas dimana $r$ ca di bandingkan dengan $r$ tabel pada setiap variabel kuisioner nya:

a. Lingkungan Kerja, memperoleh nilai $r$ ca $(0,945)>r_{\text {tabel }}(0,235)$ sehingga kusioner variabel Lingkungan Kerja dikatakan reliabel.

b. Stres Kerja, memperoleh nilai $r_{\text {ca }}(0,828)>r_{\text {tabel }}(0,235)$ sehingga kusioner variabel Stres Kerja dikatakan reliabel

c. Kinerja Karyawan memperoleh nilai $r_{\text {ca }}\left(0,926>r_{\text {tabel }}(0,235)\right.$ sehingga kusioner variabel Lingkungan Kerja dikatakan reliabel

\section{Uji Asumsi Klasik}

\section{Uji Normalitas}

Menurut Ghozali (2005: 73), "Uji normalitas digunakan untuk melihat apakah nilai residual terdistribusi normal atau tidak. Model regresi yang baik adalah memiliki nilai residual yang terdistribusi normal. Jadi uji normalitas bukan dilakukan pada masingmasing variabel tetapi pada nilai residualnya." Ghozali juga menjelaskan, "Jika data menyebar di sekitar garis diagonal dan mengikuti arah garis diagonal atau grafik histogramnya menunjukkan pola distribusi normal, maka model regresi memenuhi asumsi normalitas."

Tabel 1.1 Uji Normalitas

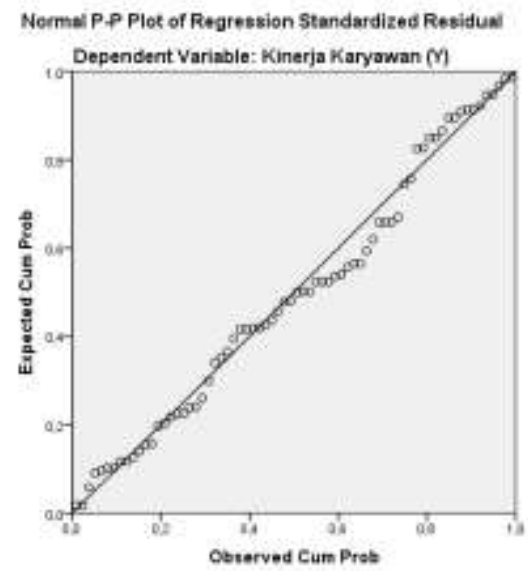

Sumber: Hasil Olah Data Penelitian 
Dapat dilihat, "Dari grafik diatas bahwa titik - titik menyebar disekitar garis dan mengikuti garis diagonal, dapat diartikan bahwa nilai residual yang dihasilkan dari regressi tersebut normal."

\section{Uji Multikolinearitas}

"Dalam penelitian ini uji multikolinieritas digunakan untuk menguji apakah ada korelasi diantara Variable Lingkungan Kerja, dan Stres Kerja. Model regresi yang tidak ada multikolinieritas adalah yang mempunyai nilai besaran korelasi antar variable bebas kurang dari 95\% VIF (Variance Inflation Factor) kurang dari 10 dan mempunyai nilai tolerance lebih dari 0.1 atau 10\%." Ghozali (2005:91), "Pengujian ada tidaknya gejala multikolinieritas dilakukan dengan mempertahankan nilai matriks korelasi yang dihasilkan pada saat pengolahan data serta nilai VIF (Variance Inflation Factor) dan tolerance sebagai berikut":

Tabel. 1.2 Uji Multikolinearitas

\begin{tabular}{|ll|r|r|}
\hline \multirow{2}{*}{ Model } & \multicolumn{2}{|l|}{ Collinearity Statistics } \\
\cline { 3 - 4 } & & \multicolumn{1}{l|}{ Tolerance } & \multicolumn{1}{l|}{ VIF } \\
\hline 1 & $\begin{array}{l}\text { (Constant) } \\
\text { Lingkungan } \\
\text { Kerja }\end{array}$ &, 663 & \\
& Stres Kerja &, 663 & 1,508 \\
& & & 1,508 \\
\hline
\end{tabular}

a. Dependent Variable: (Y) Kinerja Karyawan

Sumber: Hasil Olah Data Penelitian

Dari hasil output data didapatkan bahwa nilai VIF $<10,00$ dan nilai tolerance $>0,10$ maka tidak terjadi gejala multikolineritas.

\section{Uji Heteroskedastisitas}

Uji Heteroskedastisitas ini "Untuk menguji apakah dalam model regresi terdapat ketidaksamaan variance dan residual satu pengamatan ke pengamatan yang lain. Jika variance dari residual satu pengamatan ke pengamatan lain tetap, maka disebut homoskedastisitas, karena data ini menghimpun data yang mewakili berbagai ukuran (kecil, sedang dan besar)." Ghozali (2005:93).

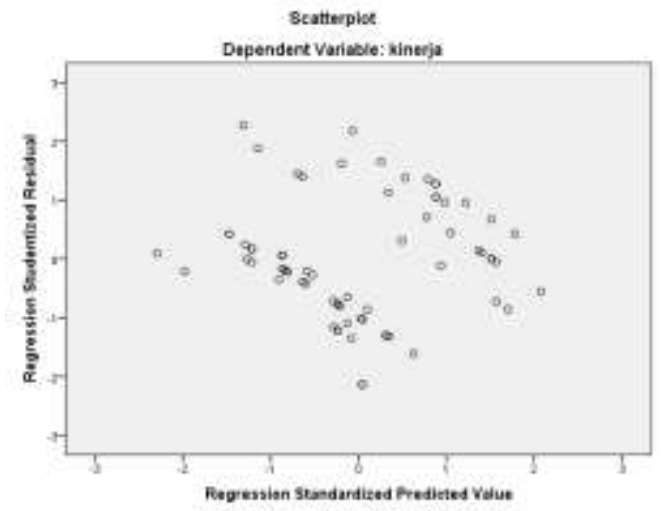

Gambar. 1.1 Uji Heteroskedastisitas 
Dari output di atas "Dapat diketahui bahwa titik-titik tidak membentuk pola yang jelas, dan titik-titik menyebar di atas dan di bawah angka 0 pada sumbu $Y$, jadi dapat disimpulkan bahwa tidak terjadi masalah heteroskedastisitas dalam model regresi."

\section{Analisis Regresi Linear Berganda}

Tabel 1.3 Analisis Regresi Linier Berganda Coefficients ${ }^{\mathbf{a}}$

\begin{tabular}{|c|c|c|c|c|c|c|}
\hline \multirow[b]{2}{*}{ Mode } & & \multicolumn{2}{|c|}{$\begin{array}{c}\text { Unstandardized } \\
\text { Coefficients }\end{array}$} & \multirow{2}{*}{$\begin{array}{c}\text { Standardized } \\
\text { Coefficients } \\
\text { Beta }\end{array}$} & \multirow[b]{2}{*}{$t$} & \multirow[b]{2}{*}{ Sig. } \\
\hline & & B & $\begin{array}{l}\text { Std. } \\
\text { Error }\end{array}$ & & & \\
\hline \multirow[t]{4}{*}{1} & (Constant) & 3,895 & 8,503 & & ,458 &, 648 \\
\hline & Lingkungan Kerja & & & & & \\
\hline & (X1) &,- 242 &, 083 &,- 318 & $-2,929$ &, 005 \\
\hline & Stres Kerja (X2) & 1,362 &, 179 & ,825 & 7,609 &, 000 \\
\hline
\end{tabular}

a. Dependent Variable: Kinerja Karyawan (Y)

\section{Sumber: Hasil Olah Data Penelitian}

Model Regresi yang diperoleh $\mathrm{Y}=3,895-0,242 \mathrm{X}_{1}+\mathbf{1 , 3 6 2 \mathrm { X } _ { 2 }}$

1. Konstanta $(\alpha)$ sebesar " 3,895 menyatakan bahwa tanpa variabel Lingkungan Kerja (x1) dan Stres Kerja (x2) maka besarnya nilai Kinerja Karyawan (y) adalah 3,895".

2. Variabel "Lingkungan Kerja $\left(x_{1}\right)$ berpengaruh negatif terhadap Kinerja Karyawan $(y)$ dengan nilai koefisiensi sebesar $-0,242$, yang artinya jika variabel Lingkungan Kerja $\left(x_{1}\right)$ meningkat satu satuan dengan asumsi variabel Stres Kerja $\left(\mathrm{x}_{2}\right)$ tetap, maka Kinerja Karyawan $(\mathrm{y})$ akan meningkat sebesar -0,242, sehingga besarnya pengaruh Lingkungan Kerja $\left(x_{1}\right)$ terhadap Kinerja Karyawan (y) sebesar -24,2\%."

3. Variabel "Stres Kerja $\left(\mathrm{x}_{2}\right)$ berpengaruh positif terhadap Kinerja Karyawan ( $\mathrm{y}$ ) dengan nilai koefisien sebesar 1,362 yang artinya jika variabel Stres Kerja $\left(\mathrm{x}_{2}\right)$ meningkat satu satuan dengan asumsi variabel Lingkungan Kerja $\left(\mathrm{x}_{1}\right)$ tetap, maka Kinerja Karyawan (y) akan meningkat sebesar 1,362. Sehingga besarnya pengaruh stres kerja terhadap Kinerja Karyawan sebesar 136,2\%."

\section{Koefisien Korelasi Berganda}

Tabel 1.4 Analisis Korelasi Berganda Model Summary

\begin{tabular}{|l|l|l|l|l|}
\hline Model & $\mathrm{R}$ & R Square & $\begin{array}{l}\text { Adjusted } \\
\text { Square }\end{array}$ & $\begin{array}{l}\text { R } \\
\text { Std. Error of the } \\
\text { Estimate }\end{array}$ \\
\hline 1 &, $691^{\mathrm{a}}$ &, 477 &, 462 & 4,575 \\
\hline
\end{tabular}

a. Predictors: (Constant), Stres Kerja, Lingkungan Kerja

Sumber: Hasil Olah Data Penelitian 
Dari "Hasil Korelasi berganda antara Hubungan Lingkungan Kerja dan Stres Kerja terhadap Kinerja $\left(X_{1}\right.$ dan $X_{2}$ terhadap $Y$ ) adalah 0,691 . Hal ini menunjukkan bahwa terdapat hubungan yang kuat antara Lingkungan Kerja dan Stres Kerja terhadap kinerja karyawan."

\section{Koefisiensi determinasi}

Mengacu pada Tabel 1.4 Analisis Korelasi Berganda Dari "Hasil Koefisien Determinasi $\left(\mathrm{R}^{2}\right)$ Lingkungan Kerja dan Stres Kerja terhadap Kinerja, diperoleh dari $R^{2} \times 100 \%$, yaitu $0,691^{2} \times 100 \%=47,7 \%$, menunjukkan bahwa prosentase sumbangan pengaruh Lingkungan Kerja $\left(\mathrm{x}_{1}\right)$ dan Stres Kerja $\left(\mathrm{x}_{2}\right)$ terhadap variabel kinerja karyawan (y) adalah sebesar $47,7 \%$, sedangkan sisanya sebesar $52,3 \%$ dipengaruhi oleh variabel lain yang tidak dimasukkan dalam penelitian ini”.

\section{Uji Hipotesis}

a. Uji T

\section{Tabel 1.5 Hasil Uji T}

Coefficients ${ }^{a}$

\begin{tabular}{|c|c|c|c|c|c|c|}
\hline \multirow[b]{2}{*}{ Mod } & & \multicolumn{2}{|c|}{$\begin{array}{l}\text { Unstandardized } \\
\text { Coefficients }\end{array}$} & \multirow{2}{*}{$\begin{array}{c}\text { Standardized } \\
\text { Coefficients } \\
\text { Beta }\end{array}$} & \multirow[b]{2}{*}{$t$} & \multirow[b]{2}{*}{ Sig. } \\
\hline & & B & $\begin{array}{l}\text { Std. } \\
\text { Error }\end{array}$ & & & \\
\hline \multirow[t]{4}{*}{1} & (Constant) & 3,895 & 8,503 & &, 458 &, 648 \\
\hline & Lingkungan Kerja & & & & & \\
\hline & (X1) &,- 242 & ,083 &,- 318 & $-2,929$ &, 005 \\
\hline & Stres Kerja (X2) & 1,362 & , 179 & ,825 & 7,609 &, 000 \\
\hline
\end{tabular}

\section{a. Dependent Variable: Kinerja Karyawan ( $Y$ )}

\section{Sumber: Hasil Olah Data Penelitian}

1) Lingkungan Kerja ( $\left.X_{1}\right)$ terhadap Kinerja Karyawan ( $Y$ )

Berdasarkan di atas dapat dilihat bahwa "Variabel Lingkungan Kerja $\left(\mathrm{x}_{1}\right)$ diperoleh signifikansi t lebih kecil dari 0,05 $(0,005<0,05)$ dan $\mathrm{t}$ hitung $-2,929<$ $\mathrm{t}$ tabel sebesar $-2,929(-2,929<1,668)$ atau berarti $\mathrm{H}_{01}$ diterima dan $\mathrm{H}_{\mathrm{a} 1}$ ditolak, hal ini menunjukan bahwa tidak terdapat pengaruh yang signifikan dari Lingkungan Kerja $\left(\mathrm{x}_{1}\right)$ terhadap Kinerja Karyawan $(\mathrm{y}) . "$

2) Stres Kerja $\left(X_{2}\right)$ terhadap Kinerja Karyawan $(Y)$

Berdasarkan tabel diatas dapat dilihat bahwa "Variabel Stres Kerja (x2) diperoleh signifikansi t lebih kecil dari 0,05 $(0,000<0,05)$ dan $t_{\text {hitung }} 7,609>$ $\mathrm{t}_{\text {tabel }}$ sebesar $1,668(7,609>1,668)$ atau berarti $\mathrm{H}_{02}$ ditolak dan $\mathrm{H}_{\mathrm{a} 2}$ diterima, hal ini menunjukan bahwa terdapat pengaruh yang signifikan dari Stres Kerja $\left(\mathrm{x}_{2}\right)$ terhadap Kinerja Karyawan $(\mathrm{y}) . "$

b. Uji F

Untuk menguji pengaruh Lingkungan Kerja $\left(\mathrm{x}_{1}\right)$ dan Stres Kerja $\left(\mathrm{x}_{2}\right)$ secara bersama-sama terhadap Kinerja Karyawan $(\mathrm{y})$, dapat digunakan uji statistik $\mathrm{F}$ (uji F), dengan menggunakan taraf signifikansi $5 \%(0,05)$. 
Tabel 1.6 Hasil Uji F

ANOVA

\begin{tabular}{|ll|l|r|l|l|l|}
\hline Model & & $\begin{array}{l}\text { Sum of } \\
\text { Squares }\end{array}$ & df & \multicolumn{1}{l|}{$\begin{array}{l}\text { Mean } \\
\text { Square }\end{array}$} & F & Sig. \\
\hline 1 & Regression & 1281,298 & 2 & 640,649 & 30,613 &, $000^{\mathrm{b}}$ \\
& Residual & 1402,145 & 67 & 20,928 & & \\
& Total & 2683,443 & 69 & & & \\
\hline
\end{tabular}

a. Dependent Variable: Kinerja Karyawan

b. Predictors: (Constant), Stres Kerja, Lingkungan Kerja

\section{Sumber: Hasil Olah Data Primer}

Dari "Hasil uji $F$ dapat diperoelh nilai $f_{\text {hitung }}>f_{\text {tabel }}$ yaitu $30,613>3,13$ dan nilai sig $<0,05$ atau 0,000 0,05 "Maka, Lingkungan Kerja dan Stres Kerja secara simultan memiliki pengaruh yang signifikan terhadap Kinerja Karyawan"

\section{G. Analisis Hasil Penelitian dan Pembahasan}

\section{Lingkungan Kerja}

a. Dari hasil uji validitas dan reliabilitas maka "Instrument kuisioner menunjukan valid seperti instirumen kuisioner no $1(0,946>0,235)$ dan begitupun hasil uji reliabilitas kuisioner dimana nilai $r$ ca $(0,945)>r$ tabel $(0,235)$ dinyatakan reliabel."

b. Dari hasil uji analisis regresi berganda, diperoleh "nilai koefisien -0,242, sehingga besarnya pengaruh Lingkungan Kerja $\left(x_{1}\right)$ terhadap Kinerja Karyawan (y) sebesar $-24,2 \%$."

c. Dan hasil uji hipotesis, "Yaitu uji t antara Lingkungan Kerja terhadap Kinerja Karyawan maka diperoleh nilai $\mathrm{t}_{\text {hitung }}-2,929<\mathrm{t}$ tabel sebesar 1,668 (-2,929 $<1,668$ ) atau berarti $\mathrm{H}_{01}$ diterima dan $\mathrm{H}_{\mathrm{a} 1}$ ditolak, hal ini menunjukan bahwa tidak terdapat pengaruh yang signifikan dari Lingkungan Kerja $\left(\mathrm{x}_{1}\right)$ terhadap Kinerja Karyawan (y)."

\section{Stres Kerja}

a. Dari hasil "Uji validitas dan reliabilitas maka instrument kuisioner menunjukan valid seperti instirumen kuisioner no $1(0,816>0,235)$ dan begitupun hasil uji reliabilitas kuisioner dimana nilai $r_{\text {ca }}(0,828)>r_{\text {tabel }}$ $(0,235)$ dinyatakan reliabel."

b. Dari hasil "Uji analisis regresi berganda maka diperoleh nilai koefisien 1,362 , sehingga besarnya pengaruh Stres Kerja $\left(\mathrm{x}_{2}\right)$ terhadap Kinerja Karyawan (y) sebesar 136,2\%."

c. Dan hasil "Uji hipotesis, yaitu uji $\mathrm{t}$ antara Stres Kerja terhadap Kinerja Karyawan diperoleh nilai $t_{\text {hitung }} 7,609>\mathrm{t}_{\text {tabel }}$ sebesar 1,668 $(7,609>1,668)$ atau berarti $\mathrm{H}_{02}$ ditolak dan $\mathrm{H}_{\mathrm{a} 2}$ diterima, hal ini menunjukan bahwa terdapat pengaruh yang signifikan dari Stres Kerja $\left(\mathrm{x}_{2}\right)$ terhadap Kinerja Karyawan (y)."

\section{Kinerja Karyawan}

a. Dari hasil "Uji validitas dan reliabilitas maka instrument kuisioner menunjukan valid seperti instirumen kuisioner no $1(0,915>0,235)$ dan 

$(0,235)$ dinyatakan reliabel."

b. Dari Hasil "Korelasi berganda antara Hubungan Lingkungan Kerja dan Stres Kerja terhadap Kinerja ( $\mathrm{X}_{1}$ dan $\mathrm{X}_{2}$ terhadap $\mathrm{Y}$ ). maka didapat korelasi antara Lingkungan Kerja dengan kinerja karyawan ( $r$ ) adalah 0,691 . Hal ini menunjukkan bahwa terjadi hubungan yang kuat antara Lingkungan Kerja dan Stres Kerja dengan kinerja karyawan."

c. Dari hasil "Koefisien determinasi dilihat dari nialai ( $R$ Square) yang diperoleh sebesar 0,477. Hal ini berarti 47,7\%, Kinerja Karyawan (y) dipengaruhi oleh variabel Lingkungan Kerja $\left(x_{1}\right)$ dan Stres Kerja $\left(x_{2}\right)$, sedangkan sisanya 52,3\% Kinerja Karyawan (y) dipengaruhi oleh variabelvariabel lain yang tidak diteliti."

d. Dan hasil "Uji hipotesis, yaitu uji $F$ maka diperoleh nilai $f$ hitung $>f$ tabel yaitu $30,613>3,13$ dan nilai sig $<0,05$ atau 0,000 $<0,05$, Maka, Lingkungan Kerja dan Stres Kerja memiliki pengaruh yang signifikan terhadap Kinerja Karyawan"

\section{H. Kesimpulan}

1. Dari hasil "Analisis regresi linier berganda maka besarnya pengaruh Lingkungan Kerja $\left(x_{1}\right)$ terhadap Kinerja Karyawan ( $y$ ) sebesar -24,2\%."

2. Dari hasil "Analisis regresi linier berganda maka besarnya pengaruh Stres Kerja $\left(\mathrm{x}_{2}\right)$ terhadap Kinerja Karyawan sebesar 136,2\%."

3. Dari hasil "Koefisien determinasi maka besarnya Lingkungan Kerja dan Stres Kerja terhadap Kinerja Karyawan sebesar 47,7\%."

\section{Saran}

1. Dikarenakan pengaruh negatif dan signifikan Lingkungan Kerja dengan Kinerja Karyawan di PT. Modernland Realty T,bk Jakarta. Karena itu berarti bahwa perusahaan harus menciptakan lingkungan kerja di PT. Modernland Realty T,bk agar mempengaruhi kinerja yang baik

2. Dikarenakan "Terdapat pengaruh positif dan signifikan antara Stres Kerja dengan Kinerja Karyawan di PT. Modernland Realty Tbk Jakarta." Maka perusahaan harus mengurangi Stres Kerja untuk menghasilkan kinerja karyawan yang lebih baik lagi.

3. Dan perlunya perusahaan lebih memperhatikan Lingkungan Kerja dan kondisi Stres Kerja karyawan, agar pencapaian Kinerja Karyawan semakin meningkat.

\section{J. Daftar Pustaka}

Arikunto, Suharsimi. 2002, "Prosedur Penelitian", Edisi Revisi V, Jakarta : Rineka Cipta.

Duwi Puritno.2013 "Analisis Korelasi, Regresi Dan Multivariate Dengan SPSS". Yogyakarta: Gava Media.

Ghozali , 2005. "Metode Penelitian", Jakarta : Penerbit Guna Dharma.

Hasibuan, Malayu. 2009, "Manajemen Sumberdaya Manusia”. PT. Bumi Aksara, Jakarta , 2012, Organisasi dan Stres Kerja, PT. Bumi Aksara, Jakarta

Mangkunegara, Anwar Prabu. 2005. "Manajemen Sumber Daya Manusia Perusahaan". Cetakan Ke Duabelas, Bandung: PT. Remaja Rosdakarya Aditama 2009. "Evaluasi Kinerja Sumber Daya Manusia”, Bandung : Rafiak

Narimawati, Umi. 2010. "Metodologi Penelitian Kuantitatif Dan Kualitatif Teori Dari Aplikasi". Bandung : Agung Media

Nitisemito, Alex S. 2002. "Manajemen Personalia”. Edisi Ketiga, Cetakan Kesembilan, Jakarta : Ghalia Indonesia. 
Prawirosentono.S, 1999. "Manajemen Sumber Daya Manusia Kebijakan Kinerja Karyawan”. BPFE, Yogyakarta.

Priyatno. 2012. "Mandiri Belajar Analisis Data Dengan SPSS". Jakarta : Mediakom

Riduwan, 2009. "Metode Dan Teknik Menyusun Proposal Penelitian", Bandung: Penerbit Alfabeta.

Robbins, Stephen P. 2007. "Perilaku Organisasi : Konsep, Kontroversi, Aplikasi." Jilid 1 dan 2. Jakarta : Penerbit Prenhallindo.

Sedarmayanti (2001). "Sumber Daya Manusia dan Produktivitas Kerja." Bandung: Mandar Maju.

Sitanggang, Crimson, 2005, "Analisis Pengaruh Prilaku Pemimpin Terhadap Kinerja Pegawai Pada Sekretariat Kotamadya Jak-Bar.” Skripsi, UNDIP Semarang.

Sondang P Siagian, 2016. "Manajemen Sumber Daya Manusia”. Jakarta : Bumi Aksara

Sugiyono. 2006 "Metode Penelitian Kuantitatif, Kualitatif, dan R\&D”. Bandung : Alfabeta 2009 "Statistika Untuk Penelitian". Cetakan ke-25. CV. Bandung : Alfabeta, 2013, "Metode Penelitian Kombinasi", Cetakan Ke Tiga, Bandung : Alfabeta.

Sutrisno, Edy. 2010. "Manajemen Sumber Daya Manusia". Jakarta: Kencana

Suwatno. 2001. "Asas-Asas Manajemen Sumber Daya Manusia”, Bandung: Suci Press

Tri, Heru, Al Fajar dan Siti. 2010. "Manajemen Sumberdaya Manusia". Yogyakarta : Sekolah Tinggi IImu Manajemen YKPN

Umar , H. 1997. "Metodologi Penelitian-Aplikasi Dalam Pemasaran”,Jakarta : Gramedia Pustaka Utama.

Veithzal, Rivai. 2014. "Manajemen Sumber Daya Manusia”. Jakarta: PT. Raja Grafindo Persada. 